\title{
Immunocytochemical localisation of renin in nephroblastoma
}

\author{
GBM LINDOP, S FLEMING, AAM GIBSON* \\ From the University of Glasgow, Department of Pathology, Western Infirmary, and the *Department of \\ Pathology, Royal Hospital for Sick Children, Glasgow
}

SUMMARY An antibody to pure human renin and an immunoperoxidase technique were used to stain immunoreactive renin in nephroblastomas. In an unselected series of surgically removed nephroblastomas immunoreactive renin was found in 10 of 19 tumours $(53 \%)$. Tissue obtained at necropsy from 12 cases of disseminated nephroblastoma was also studied, and immunoreactive renin in metastatic tumours was found in three cases. Patients' blood pressures and serum potassium concentrations showed no evidence of excess renin activity. It is therefore suggested that if nephroblastomas contain renin as commonly as this study suggests, then any hormone secreted may be biologically inactive.

Some malignant tumours secrete hormones, and there is evidence that nephroblastomas may occasionally secrete renin..$^{1-3}$ Biochemical study of the renin secreted by one of these cases showed that the hormone was mainly biologically inactive. ${ }^{4}$ This raises the possibility that nephroblastomas may secrete renin more commonly than is realised.

We have used an antibody to pure human renin and an immunoperoxidase technique to localise renin in the kidney ${ }^{5}$ and its tumours. ${ }^{6-8}$ This study reports the application of this technique to show immunoreactive renin in a series of nephroblastomas.

\section{Material and methods}

We studied 19 surgically excised primary nephroblastomas. These represent an unselected series from the files of the Pathology Department, Royal Hospital for Sick Children, Glasgow. They were fixed in neutral buffered formalin, postfixed in corrosive formol saline, and, after dehydration, embedded in paraffin wax. From each case two blocks were selected to include not only tumour but also adjacent kidney, where the renin containing cells of the juxtaglomerular apparatus provided a known positive staining reaction. Sections $(5 \mu \mathrm{m})$ were stained with haematoxylin and eosin, Wilson's stain, Bowie's stain, and periodic acid Schiff after diastase. Consecutive sections were retained for immunocytochemistry.
The peroxidase-antiperoxidase (PAP) technique modified as described previously ${ }^{7}$ was used for the identification of human renin in paraffin embedded tissue. The antiserum was raised in rabbits using human renin purified from a juxtaglomerular cell tumour as the antigen. The purity of the renin and the specificity of the antibody have been documented, ${ }^{10}$ and appropriate controls were used as previously described.?

Since we were able to localise renin in the juxtaglomerular apparatus of kidney obtained at necropsy, we also studied postmortem tissue from 12 children with disseminated nephroblastoma. We examined paraffin embedded sections of metastatic nephroblastoma in lung, liver, and lymph nodes.

All sections were examined independently by two observers (GBML and SF), and only those tumours classified as positive by both were included. The histological features were assessed by an experienced paediatric pathologist (AAMG) without knowledge of the immunocytochemical findings.

\section{Results}

\section{HISTOLOGY}

The series of nephroblastomas included a full range of differentiation: well and poorly differentiated mesenchyme and well and poorly differentiated epithelial structures. A comparison of the nature and degree of differentiation of the tumours showed no relation between the morphological assessment 
of differentiation and the presence or absence of cells containing immunoreactive renin.

\section{IMMUNOCYTOCHEMISTRY}

The renin containing cells in the juxtaglomerular apparatus of the kidney adjacent to the tumours

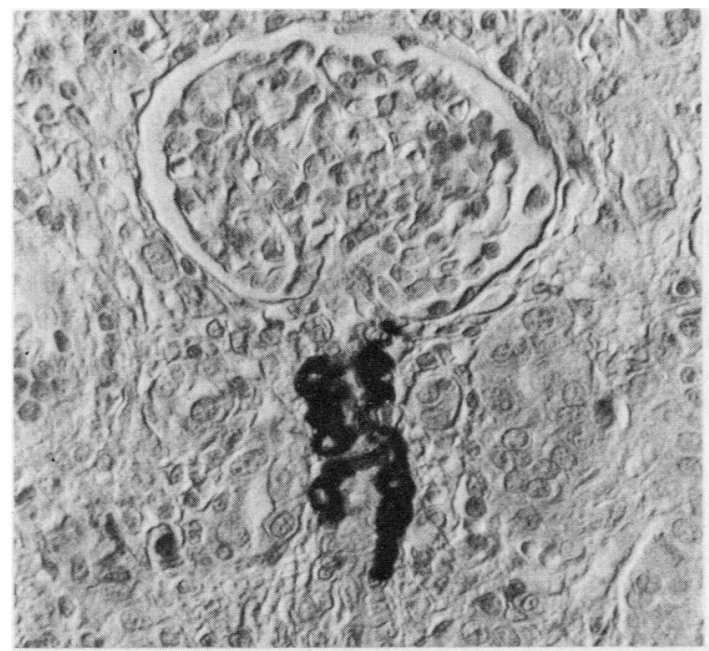

Fig. 1 Glomerulus with its afferent arteriole in the kidney adjacent to a nephroblastoma which contains immunoreactive renin. There is hyperplasia of the juxtaglomerular renin secreting cells. Renin PAP. Interference contrast microscopy. Original magnification $\times 160$.

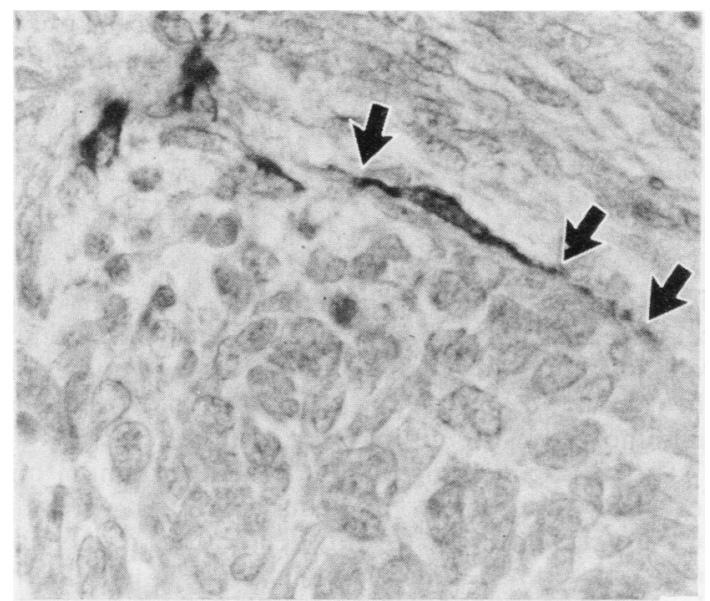

Fig. 2 Nephroblastoma showing four cells containing immunoreactive renin. One is a spindle cell with long cytoplasmic processes (arrows) which contain granular deposits of immunoreactive renin. Renin PAP. Original magnification $\times 630$.

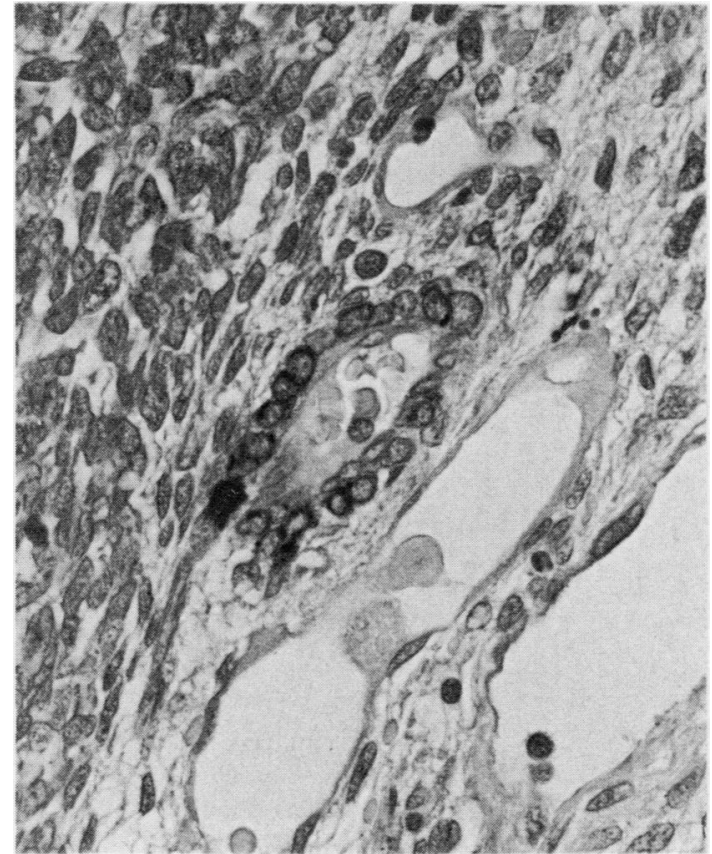

Fig. 3 Renin positive cells are in the better differentiated mesenchyme of the tumour. They are more rounded with round nuclei and are clearly perivascular Renin PAP. Original magnification $\times 396$.

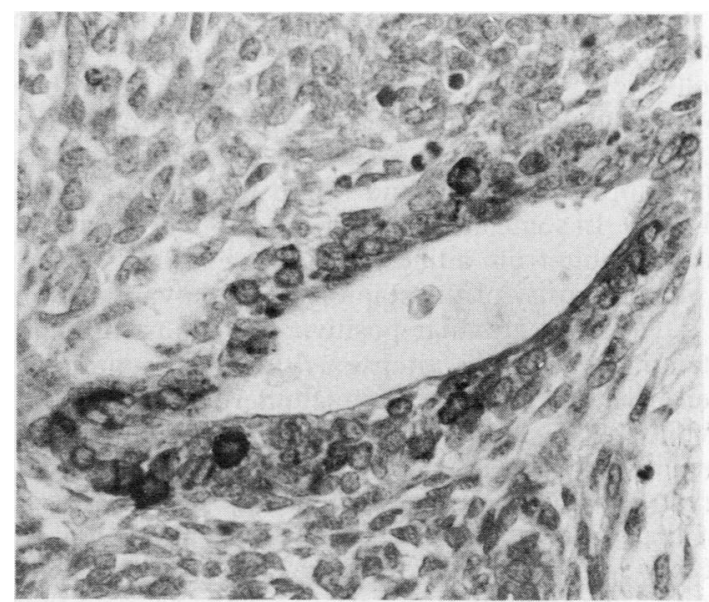

Fig. 4 Dilated blood vessel at the junction of the undifferentiated blastema and mesenchyme of $a$ nephroblastoma with tumour cells round the blood vessel. The cells containing immunoreractive renin are cytologically indistinguishable from adjacent tumour cells. Renin PAP. Original magnification $\times 396$. 


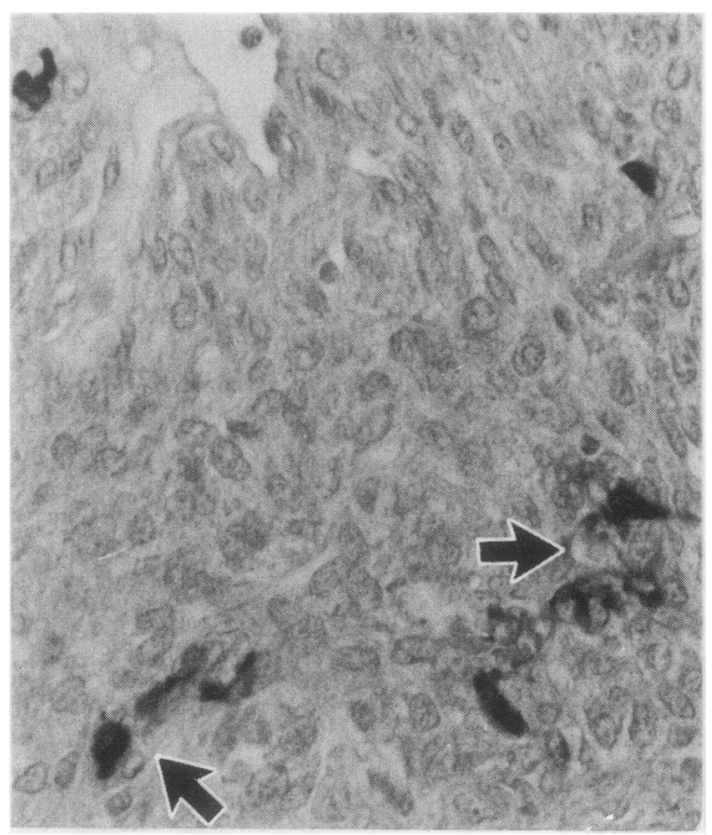

Fig. 5 Poorly differentiated blastemal area of a nephroblastoma which contains scattered renin positive cells. They are all related to small blood vessels (arrows). Renin PAP. Original magnification $\times 396$.

always showed a positive staining reaction. These cells showed cytoplasmic positivity, which was both granular and diffuse. There was often hyperplasia of cells containing immunoreactive renin (Fig. 1).

Cells containing immunoreactive renin were found in 10 of 19 primary nephroblastomas. These cells were variable in size and morphology. They were sometimes spindle cells with oval nuclei and long cytoplasmic processes (Fig. 2); at other times they appeared plump and round with round nuclei (Fig. 3). In some areas they were cytologically indistinguishable from adjacent tumour cells (Fig. 4).

The intensity of the staining reaction varied from a pale brown granular positivity to almost black, a staining reaction as intense as the renin containing cells in the adjacent juxtaglomerular apparatus. While the appearance and intensity of staining of the renin positive cells varied, their position was constant: they were always related to the blood vessels of the tumour. These varied from small capillaries (Fig. 5) to large dilated thin walled vessels (Figs. 3 and 4). Examination of serial sections showed that when apparently isolated positive cells were seen (Fig. 2) adjacent sections showed that they were usually related to an underlying blood vessel. The cells containing immunoreactive renin were usually close to the blood vessels but external to the endothelium (Figs. 3, 4 and 5). The renin containing cells were most commonly found in the well differentiated mesenchyme of the tumours, and often they were on the border between this tissue and the undifferentiated metanephric blastema. Occasionally, cells containing immunoreactive renin were found within areas of undifferentiated blastema, always close to capillary blood vessels within the tumour (Fig. 5).

We found immunoreactive renin in metastatic nephroblastoma from three of the 12 postmortem cases studied. The metastatic sites were lung, liver, and lymph node. The distribution of the renin positive cells in the metastatic nephroblastoma was identical to that of the primary tumours in the kidney.

Sections stained with aldehyde fuchsin and Bowie's stains showed granular cells associated with the blood vessels in a similar position to the renin containing cells in the adjacent sections stained with the renin PAP method.

\section{CLINICAL MEASUREMENTS}

Blood pressure measurements and serum potassium concentrations were obtained from the clinical case records where available. Where there was more than one measurement the mean was used. There was no significant difference (Student's $t$ test) in the blood pressure measurements between children whose tumours contained cells positive for immunoreactive renin (mean 124/79 $\mathrm{mmHg}$ ) and those whose tumours contained negative cells (mean 110/74 $\mathrm{mmHg}$ ). After nephrectomy no significant difference in blood pressure was recorded in either group as a whole or in individual cases. Similarly, there was no difference in serum potassium concentration between the renin positive group (mean $4.1 \mathrm{mmol} / \mathrm{l}$ ) and the renin negative group (mean $4.1 \mathrm{mmol} / \mathrm{l}$ ). These measurements were also unaffected by nephrectomy.

\section{Discussion}

The in vitro specificity of this renin antiserum is well characterised..$^{10}$ It has been found to stain renin reliably with the PAP technique in several studies of the kidney, ${ }^{11-13}$ and we have used it to detect immunoreactive renin in other renal tumours. ${ }^{68}$

The cells containing immunoreactive renin in this series of nephroblastomas could have grown into primary renal tumours from the adjacent renal cortex along with the blood vessels, since it is thought that tumours stimulate the growth of blood vessels from the surrounding tissue. ${ }^{14}$ But this would not explain their presence in metastatic nephroblastoma in other organs. Moreover, our previous study failed to show immunoreactive renin in metastatic tumours 
growing in the renal cortex. ${ }^{8}$ In some of the cases which we have studied there were renin positive cells which were cytologically malignant and indistinguishable from adjacent tumour cells. It therefore seems likely that the renin containing cells in nephroblastoma are tumour cells.

The renin in these cells could either have been taken up from the plasma or synthesised by the cells in the tumour. The renin staining was often granular (like the juxtaglomerular renin secreting cells in the adjacent kidney), and occasional cells contained granules with the staining reactions of renin storage granules.

The renin secreting cells in the kidney are thought to be derived from undifferentiated mesodermal cells adjacent to the blood vessels in the metanephric renal cortex. ${ }^{15}$ Nephroblastoma is a tumour of pluripotent mesodermal cells which can differentiate into all structures of the normal kidney. It is therefore not surprising that it can differentiate into renin secreting cells and that these renin secreting cells would be associated with the blood vessels, mimicking the known development pattern for juxtaglomerular cells. ${ }^{15}$

There are several descriptions of renin secreting nephroblastomas..$^{1-316-18}$ The evidence is based on high concentrations of renin in the preoperative plasma and in the tumour, and normal plasma concentrations after nephrectomy. In two cases ${ }^{1617}$ ultrastructural examination showed secretory granules with morphological features consistent with renin granules within tumour cells. The situation of these granular cells within the tumours was not described. Patients with renin secreting tumours often have evidence of increased renin activity in the form of hypertension and hypokalaemia. ${ }^{19} 20$ These are usually cured by nephrectomy. Analysis of the clinical case records in our series showed no significant difference in the blood pressure values or serum potassium concentations between those cases whose tumours contained immunoreactive renin and those cases whose tumours did not. Moreover, these variables were not affected by nephrectomy. Thus there was no clinical evidence of excess renin activity. In support of this conclusion is the fact that there was often hyperplasia of the renin containing juxtaglomerular cells in the adjacent kidney. Previously described renin secreting nephroblastomas have had absent renin activity ${ }^{1}$ and absent granular cells ${ }^{17}$ in the adjacent kidney, as has been described in other renin secreting tumours. ${ }^{6}$ It is possible either that the renin containing cells which we have shown to be commonly present in nephroblastoma did not release the hormone in amounts sufficient to raise plasma angiotensin II concentrations (and hence suppress physiological renin secretion) or that any hormone secreted was biologically inactive. Whether or not nephroblastoma commonly secretes renin will be decided by the biochemical measurements of renin concentrations in tumour tissue, adjacent kidney, and in pre- and postoperative plasma. which are now underway.

We have found a similar distribution of cells containing immunoreactive renin in a series of renal cell carcinomas. ${ }^{8}$ Interestingly, the renin positive cells were also usually close to the blood vessels of the tumour, and in one case studied in detail ${ }^{7}$ the renin secreted by the tumour was shown to be mainly biologically inactive and to have a higher molecular weight than active renin.' It may therefore have been a prohormone. Similarly, the biochemistry of the renin present in the tumour and the plasma from one case of renin secreting nephroblastoma' has been studied in detail: it was mainly biologically inactive, had a higher molecular weight, and was also probably a prohormone. ${ }^{4}$

The antibody used in the present study binds to both active and inactive renin in vitro. ${ }^{422}$ Hence the biological nature of the immunoreactive renin which we have shown to be present in these tumours remains to be elucidated. Our work suggests that while secretion of biologically active renin by nephroblastoma may be rare, as in other tumours ${ }^{24}$ secretion of biologically inactive hormone may be common.

We are grateful to Professor Pierre Corvol and Professor Joel Menard of Inserm u36 7005 Paris for the generous gift of the antibody, which made this work possible.

\section{References}

${ }^{1}$ Mitchell JD, Baxter TJ, Blair-West JR, McCredie DA. Renin levels in nephroblastoma (Wilms' tumour). Report of a renin secreting tumour. Arch Dis Childh 1970;45:376-84.

${ }^{2}$ Masovari I, Kontor, Kallay K. Renin-secreting Wilms' tumour (Letter). Lancet 1972;i:1180.

${ }^{3}$ Ganguly A, Gribble J, Tune B, Kempson RL, Luetscher A. Renin secreting Wilms' tumour with severe hypertension. Ann Int Med 1973;79:835-7.

4 Day RP, Luetscher JA. Big renin: a possible prohormone in kidney and plasma of a patient with Wilms' tumour. J Clin Endocrinol Metab 1974;38:923-6.

${ }^{5}$ Lindop GBM, Reid R, Downie TT, et al. Blood vessels and blood pressure. In: Woolf $\mathrm{N}$, ed, The biology and pathology of the vessel wall. Eastbourne: Praeger, 1983.

- Lindop GBM, Stewart JA, Downie TT. The immunocytochemical demonstration of renin in a juxtaglomerular cell tumour by light and electron microscopy. Histopathology 1983; 7:421-31.

${ }^{7}$ Lindop GBM, More IAR, Leckie B. An ultrastructural and immunocytochemical study of a renal carcinoma secreting inactive renin. J Clin Pathol 1983;36:639-45.

${ }^{8}$ Lindop GBM, Fleming S. Renin in renal cell carcinoma-an immunocytochemical study. J Clin Pathol 1984;37:27-31.

${ }^{9}$ Galen FX, Devaux C, Guyenne TT, Menard J, Corvol P. Multi- 
ple forms of human renin: purification and characterisation. $J$ Biol Chem 1979;254:4848-55.

${ }^{10}$ Galen FX, Guyenne T, Devaux C, Auzan C, Corvol P, Menard J. Direct radioimmunoassay of human renin. J Clin Endocrinol Metab 1979; 48: 1041-3.

" Menard J, N Goc J, Bariety J, Guyenne PT, Corvol P. Direct radioimmunoassay and immunocytochemical localization of renin in human kidneys. J Clin Sci 1979;57:105s-8s

12 Camilleri JP, Phat VN, Bariety J, Corvol P, Menard J. Use of a specific antiserum for renin detection in human kidney. $J$ Histochem Cytochem 1980;28:1343-6.

${ }^{13}$ Nochy D, Barres D, Camilleri JP, Bariety J, Corvol P, Menard J. Abnormalities of renin-containing cells in human glomerular and vascular disease. Kidney Int 1983;23:375-9.

${ }^{14}$ Folkman J, Merler E, Abernethy C, Williams G. Isolation of a tumour factor responsible for angiogenesis. J Exp Med 1971;133:275-88.

is Phat VN, Camilleri JP, Bariety J, Corvol P, Menard J. Immunohistochemical characterization of renin-containing cells in the human juxtaglomerular apparatus during embryonal and fetal development. Lab Invest 1981;45:38790.

${ }^{16}$ Luciani JC, Baldet P, Dumas R, Jean R. Etude du systeme renine-angiotensine dans deux cas de tumeur de Wilms avec hypertension arterielle severe. Arch Franc Pediat 1979;36:240-9.

17 Sheth KJ, Tang TT, Blaedel ME, Good TA. Polydipsia, polyuria and hypertension associated with renin-secreting Wilms' tumour. J Pediatr 1978;92:921-4.

${ }^{18}$ Spahr J, Demers LM, Shochat SJ. Renin producing Wilms' tumour. J Pediatric Surg 1981; 16:32-4.

${ }^{14}$ Brown JS, Fraser R, Lever AF et al. Hypertension and secondary hyperaldosteronism associated with a renin secreting renal juxtaglomerular-cell tumour. Lancet 1973;ii:1228-31.

${ }^{20}$ Schambelen M, Howes EL, Stocbigt JR, Noukes CVA, Bigleri EG. Role of renin and aldosterone in hypertension due to a renin secreting tumour. Am J Med 1973;55:86-92.

${ }^{21}$ Leckie BJ, McConnell A, Grant J, Morton JJ, Tree M, Brown JJ An inactive renin in human plasma. Circ Res 1977; 40(suppl 1):46-51.

${ }^{22}$ Guyenne TT, Galen FX, Devaux C, et al. Direct radioimmunoassay of human renin. Hypertension 1980; 2:465-70.

${ }^{23}$ Odell WD, Wolfsen AR. Humoral syndromes associated with cancer. Ann Rev Med 1978;29:379-406.

Requests for reprints to: Dr GBM Lindop, Pathology Department, Western Infirmary, Glasgow G11 6NT, Scotland. 